\title{
The Ordines Romani and the Carolingian Choreography of a Liturgical Route to Rome
}

\begin{abstract}
This article examines a number of Carolingian liturgical manuscripts (Wolfenbuttel Herzog August Bibliothek Wissembourg 91, Cologne Dombibliothek MS 138, Vienna Österreichische Nationalbibliothek cod.ser.n. 2762 and Paris Bibliothèque de l'Arsenal 227) each containing texts now known as the ordines romani. These texts are "stage directions" for the liturgy, distinguished by their reference to the practices of the Church of Rome. While the ordines romani certainly give precious information about Roman liturgical practice, the Frankish contribution to shaping and displaying these texts in line with their own priorities and usages must be acknowledged too. For example, these manuscripts all combine ordines romani with texts about Roman history and topography. For these readers, the desired imitation of Roman liturgical practice was not about copying any particular text or practice by rote, but a deeper form of participation that involved the construction of an image of Rome across a whole manuscript. The given image of Rome responded to the institutional or personal needs animating the manuscript. These manuscripts compel us to imagine diverse practices of reading within and without liturgical performance.
\end{abstract}

\section{Introduction: The Carolingian appropriation of Rome}

Rome was a constant beacon of inspiration to the Carolingian Franks, notably in its liturgical practices. The papal city had, of course, always loomed large in the religious imagination of the West and it is a mistake to present the Carolingian reception of Roman liturgy as a complete break in liturgical history, or as a simple 'reform' that replaced a native Gallican liturgy wholesale with Roman traditions. ${ }^{1}$ Nevertheless, the Carolingian interest in Roman liturgical practices was new in the intensity and breadth of surviving sources. The Carolingian period, for historiographical convenience, spans 750-888. This period witnessed innovation in some of the methods used to appropriate Roman practices, including new kinds of manuscripts and texts. Since the liturgical priorities and interventions of the individual members of the Carolingian dynasty were rather limited and never prioritised any single form of Roman text, it was left to their eager subjects in an intellectually charged and widely communicating Church to create and promulgate texts and manuscripts. In these diverse manuscripts we do not find a central 'reform' agenda, but many local or even personal ones, which most often include a

\footnotetext{
${ }^{1}$ Andrieu 1931-1962, vol. I 1965, 467-493; useful cautions in Hen 2001, 62; on the "Carolingian liturgical project", Hen 2001; McKitterick 1997; Bullough 1991.
} 
picture of Roman practice that was useful in each given context. Among them, the texts known as ordines romani are central. ${ }^{2}$ A new type of liturgical description, these texts focus principally, though not exclusively, on the actions and gestures that made up ritual (sometimes called "stage directions" for liturgy) and they make conspicuous reference to the Church of Rome. The manuscripts transmitting and interpreting these texts give us some of the new ways the Carolingians used Roman texts to transform their understanding of themselves, their own liturgical practices, and the inheritance of Rome itself.

We gain new insight into these processes of transformation and the mindset underlying them, once we allow that liturgical manuscripts were put together with purpose. Through the Middle Ages, liturgy was not a sterile or innately conservative endeavour in practice, but was profoundly engaged in the practices of compilation and knowledge transmission that characterised its age. The different texts placed together in a manuscript, both 'liturgical texts' proper, and those which addressed history, law or custom, were intended to guide reading and interpretation. At the same time as describing liturgical rituals, manuscripts propagandize for, explain and reflect upon these texts. These texts, too, unlock their individual purpose only in relation to the whole. ${ }^{3}$ We therefore gain insight into the intended messages and purposes a text might have had, when we read the entire manuscript. For example, Carolingian manuscripts might draw a picture of Rome where the city's history, topography and liturgical example all blended into one sublime picture of sanctity which could be absorbed and contemplated, before any ritual was even begun. The great edition of the ordines romani by Michel Andrieu had a different priority to this relatively new conception of how liturgical manuscripts might work. Andrieu's study was principally focused on Roman practices and the development of the 'Roman rite'. The adjustments and reinterpretations by Carolingian writers were not often a feature in his analysis, except as a barrier to the recovery of Roman originals. But it is interesting now to ask why the Carolingians copied these texts into certain manuscripts, what use they might have made of them, and what picture of Rome these texts present.

\section{A "Pontifical" for a Carolingian Bishop of Worms}

The manuscript now under the shelf-mark Wolfenbüttel Herzog August Bibliothek Cod.Guelf. Wissembourg 91 (4175) is a composite book, made up of five originally separate Carolingian manuscripts which came to Wolfenbüttel from the Abbey of Wissembourg. ${ }^{4}$ One of them is a highly interesting and individualised set of ordines romani (among other texts) that provides a good example of how texts describing the Roman liturgy were re-employed and redeployed by the Carolingians. It now covers Wissembourg $9125 \mathrm{r}-88 \mathrm{v}$ and is dated to the very beginning of the ninth century. ${ }^{5}$ It is a finely written manuscript with a complex system of rubrication and a clear textual hierarchy to guide readers. Andrieu (and after him, Vogel) deemed this text to be a "pontifical", which is, in the modern terminology, a book created for

\footnotetext{
${ }^{2}$ Texts edited in five volumes by Andrieu 1931-1962, manuscripts listed in volume I 1965.

${ }^{3}$ In this, inspired particularly by Parkes 2015; Gittos and Hamilton 2015.

4 Andrieu 1931-1962, vol. I 1965, 453-458; Butzmann 1964, 257-268. The manuscript is digitized at http://diglib.hab.de/-wdb.php?dir=mss/91-weiss\&pointer=128.

${ }^{5}$ Bischoff 2014, 512.
} 
the liturgical use of a bishop and covering the duties peculiar to a bishop. ${ }^{6}$ Wissembourg 91 is among the manuscripts which help to nuance and expand the definition of what medieval 'pontificals' could do, distinct from the modern book to which the title is now applied. Firstly, Andrieu admitted that he only saw part of the manuscript in microfilm, and had only examined the ordines romani it contained, from fol.42v onwards. He could not see that the original manuscript also contained an important record of Roman (that is to say, papal) history. This record encompasses two letters of Pseudo-Clement to James of Jerusalem (25v-37r) (the first discussing Clement's ordination by Peter and the second ecclesiastical hierarchy, liturgical vessels and vestments), the record of the life of Pope Clement from the Liber Pontificalis (37v) (that he appointed notarii to oversee Rome's seven regions, wrote the above letters and ordained clergy in the correct season, the December Ember Day), Pseudo-Jerome's letter to Pope Damasus (38v) (on the correct time of Mass) and the decretals of Pope Gregory the Great's 595 council of the Roman Clergy (38v-42r) (among other things, ruling on the role of deacons, and against simony). ${ }^{7}$ Woven within and dialoguing more explicitly with the liturgical material, is the decretal De recipiendis et non recipiendis attributed to Pope Gelasius and directly set in Rome here (72v-77r), and the manuscript ends with a partial copy of the poem Gregorius praesul, praising Pope Gregory II for his involvement in liturgical chant $(88 \mathrm{v}) .^{8}$

These historical texts therefore all address useful liturgical matters. But they also starkly lay out Rome's claims to apostolic authority through the history of the Popes going back to Saint Peter, a story the Liber Pontificalis gave to the Carolingians, and this same source was explicit about the Popes' (often legendary) involvement in shaping the liturgy. ${ }^{9}$ As for the ordines romani, their use to direct liturgical performance was certainly a part of their function, but the manuscript itself suggests other uses for them too. A "pontifical" might be a book for liturgical use, as Andrieu supposed, but these texts clearly suggest such a book was consulted in other contexts and for other reasons too.

The liturgical content of the text provides some indication of what priorities the creators of the manuscript must have envisaged for it. As stated, the manuscript offers a series of ordines romani, but these have been subject to significant editing and intervention by their copyists. In order (after the historical texts) the liturgical texts presented are, with the numbering of Andrieu's editions:

$\begin{array}{ll}42 \mathrm{v}-52 \mathrm{r} & \text { Ordo 1: The Roman "stational" mass } \\ 52 \mathrm{r}-53 \mathrm{r} & \text { Ordo 3: a supplement adjusting the Roman mass to Frankish usages } \\ 53 \mathrm{v}-60 \mathrm{r} & \text { Ordo 11: the seven scrutinies in Lent } \\ 60 \mathrm{r}-68 \mathrm{v} & \text { A narrative of the ceremonies of Holy Week, combining } \\ & \text { Andrieu's Ordo 24, 28, 25, 28a and 26 } \\ 69 \mathrm{r}-71 \mathrm{r} & \text { Ordo 27, nn.12-18: Vigils of the Week after Easter }\end{array}$

\footnotetext{
${ }^{6}$ Andrieu 1931-1962, vol. I 1965, 417, "Il a voulu faire œuvre personnelle et composer une sorte de petit directoire épiscopal, timide ébauche du futur Pontifical”; Vogel 1986, 227.

${ }^{7}$ Pseudo-Clement at PL 130, 19-44; Pope Clement's Vita in Duchesne (ed.) 1886, 53; Pseudo-Jerome in Reynolds 1988, though he did not know Wolfenbüttel 4175; Gregory the Great's Council in PL 77, 1334-1339; in Wolfenbüttel Wissembourg 91, 38v-39r it is entitled "Incipit Decretum Beati Gregorii Papae Urbis Romae ad Clericum in Basilica Beati Petri Apostoli”.

${ }^{8}$ Gelasius' Decretal in von Dobschutz 1912; the full poem Gregorius praesul in Strecker 1923: 1068-1072; see Stäblein 1968, who did not know Wolfenbüttel 4175.

${ }^{9}$ McKitterick 2011, 28-29.
} 


$\begin{array}{ll}71 \mathrm{v}-72 \mathrm{v} & \text { Ordo 13A: Order of books read through the year } \\ 72 \mathrm{v}-77 \mathrm{r} & \text { Pseudo-Gelasian Decretal De Recipiendis et non recipiendis libris } \\ 77 \mathrm{r}-\mathrm{v} & \text { Denuntiatio for the Ember Days } \\ 77 \mathrm{v}-83 \mathrm{r} & \begin{array}{l}\text { Narrative of Ordinations, combining Roman Ordo } 34 \text { and Frankish liturgi- } \\ \text { cal material from a Gelasian Sacramentary of the Eighth Century. }\end{array} \\ 83 \mathrm{r}-84 \mathrm{r} & \text { Ordo 42: Roman narrative of the deposition of relics for church dedication. } \\ 84 \mathrm{v}-86 \mathrm{v} & \text { Ordo 41 Frankish description of church dedication } \\ 86 \mathrm{v}-88 \mathrm{r} & \text { Extracts from Ordo 15 (brief descriptions of Epiphany, Candlemas, Ash } \\ & \text { Wednesday, Lent) }\end{array}$

Wissembourg 91 created some difficulties for Andrieu's editions by combining and reshaping texts which his editions held entirely apart; one cannot find in his editions any full account of this manuscript's versions of ordination or its complex narrative of Holy Week, only extracts from them aligned to the corresponding place in the reconstructed Roman originals (for which this manuscript was, he thought, of only mediocre value). ${ }^{10}$ Furthermore, the manuscript actively combined traditions from Rome with liturgical texts written in Francia, noticeably in its treatments of Holy Week, Ordination and Church Dedication. It is therefore an excellent example of the Frankish reception and re-deployment of Roman material in a critical, self-conscious way.

To begin with, the evocation of Roman topography is a highly important feature of the ordines romani. While discussing the ceremonies of the Roman church, these texts often make significant reference to the places where these ceremonies would take place in Rome. Noticeably, Ordo Romanus 1 (here fols.42v-52r) opens with a long discourse on Rome's seven liturgical regions, and their liturgical functions in the run-up to Easter. ${ }^{11}$ As with Ordo 1's elaborate presentation of the specialised personnel of the Roman Church, it is hard to see the exact and straightforward utility of this discussion to any Frankish reader or celebrant. Yet the Carolingian testimony (including Wissembourg 91) continued to faithfully maintain this introduction describing something entirely peculiar to Rome. Furthermore, Ordo Romanus 1 is specifically framed as the "stational" mass of Rome, announced prior to the ceremony with a procession to the "station" (Ordo 1, n.24-26), where the Pope would celebrate. Reference is also made to ceremonies at Santa Maria Maggiore (Ordo 1 n.14), at San Paolo fuori le mura (Ordo 1, n.17) and the Lateran (Ordo 1, n.18). Elsewhere, the Vespers after Easter in our manuscript are also explicitly located to places in Rome, indications of topography faithfully maintained by the compiler. The Easter Day service is n.67 ad locum crucifixi i.e. Santa Croce in Gerusalemme and the ceremony then moves to n.76 ad sanctum Iohannem ad Vestem, and at $\mathrm{n} .77$ at sanctum Andream ad Crucem, oratories of the Lateran. ${ }^{12}$ The other days of the week have their own indications, including SS Cosma e Damiano (n.94, var.1) for the Sunday after Easter with the ancient Roman term for this day, in albas. ${ }^{13}$ In the midst of the ordination rituals described by the manuscript which weaves Frankish rituals of ordination among a Roman text, Ordo 34, is to be found a small text which is widely disseminated

\footnotetext{
${ }^{10}$ Andrieu 1931-1962 vol. IV 1956, 312-313, “de mediocre value...a largement retouché ses models".

${ }^{11}$ Ordo Romanus 1, nn.1-6, Andrieu 1931-1962, vol. II 1948, 67-69, "Primum omnium observandum est septem esse regiones..." etc; On the power of liturgical manuscripts to evoke or 'incarnate' space, Palazzo 2014.

${ }^{12}$ Andrieu 1931-1962, vol. III 1951, 362-366; Duchesne 1886, 242, records construction of these oratories.

${ }^{13}$ Andrieu 1931-1962, vol. III 1951, 371.
} 
in the Frankish world. This text evokes Rome's traditions under the title: ORDO QUALITER IN ROMANA SEDE APOSTOLICA ECCLESIA PRESBITERI DIACONI UEL SUBDIACONI ELEGENDI SUNT (fol.78v). ${ }^{14}$ It locates the ordinations ad sanctum petrum ubi missas celebrantur, Saint Peter's basilica.

Wissembourg 91 presents a particularly rich proof of the individual adaptation and appropriation of Roman norms to new purposes. Throughout, the compilers make many fascinating adjustments and comments which seemingly address questions arising from the narrative of the ordines romani, gaps that Frankish readers found in them and needed to be answered. Therefore, it is telling that many of these directly address Roman topography, the urban space of Rome and how that space was used liturgically. This was a particular priority in how the ordines were transmitted and adapted by their Frankish copyists. At the end of the description of Holy Week (itself a compendium of usages both Roman and Frankish), Wissembourg 91's compilers added a unique "appendix" addressing some additional liturgical questions, both the chant of the Alleluia and the performance of Mass on Easter at Santa Maria Maggiore (here ad praesepio-a traditional name referring to the crib of Jesus) and "in this station and at the other stations":

Ordo 24, n.51 var.9, Similiter ad vigilias per totam ebdomadam terni psalmi dicendi sunt et per omnes psalmos Alleluia usque octabas pentecosten omnimodis predicenda est. Dominica sancta, statio ad sanctam Mariam ad prasepio; qualiter missa celebratur superius habemus conprehensum et per reliquas stationes. ${ }^{15}$

For Ash Wednesday's description in his extracts from Ordo 15, the compiler of Wissembourg 91 is the only copyist of this text to locate the service to Santa Sabina in Rome.

Ordo 15, n.83, Primum autem ieiunium IIII feria ad sanctam Savinam publicae agitur cum cruce et turabulis simul cum laetaniis, id est post Lma et ante XLma, necnon et VI feria similiter faciunt ieiunium publica. ${ }^{16}$

In the same text, Wissembourg 91 locates the Spring Ember Day service and its 'public stations' (for which see below) to Saint Peter's basilica, again alone among the manuscripts of this text:

Ordo 15, n.84, In XLma uero, prima ebdomada, si in mense martio uenerit, IIII et VI feria seu et sabbato, omnes publicas stationes faciunt ad Sanctum Petrum in XII lectionibus. Sin autem minime in martio mense prima ebdomada uenerit, in alia uel tertia ebdomada quando pontifex iudicauerit, XII lectiones agenda sunt et ordinantur qui ordinandi sunt. ${ }^{17}$

\footnotetext{
14 “THE ORDER HOW IN THE ROMAN CHURCH, SUBDEACONS, DEACONS AND PRIESTS ARE CHOSEN".

${ }^{15}$ Andrieu 1931-1962, vol. III 1951, 297; Wolfenbüttel Wissembourg 91: 68v, "Similarly at the vigils for the whole week, three psalms are to be said and for each psalm an Alleluia, until the octave of Pentecost, when everything is done in the same manner talked about above. But on that holy Sunday, the station being at Santa Maria Maggiore, we have laid out above how the mass is to be celebrated and for all the other stations as well".

${ }^{16}$ Andrieu 1931-1962, vol. III, 1951, 115; Wolfenbüttel Wissembourg 91, 87v, "But first on Ash Wednesday a fast is done publicly, with a cross and thuribles with litanies, that is after Quinquagesima and before Quadragesima, and also on that Friday they perform public fasting".

${ }^{17}$ Andrieu 1931-1962, vol. III 1951, 115-116; Wolfenbüttel Wissembourg 91, 87v-88r, "But in the first week of Lent, if it should fall in the month of March, they all do public stations on the Wednesday, Friday and Saturday, at Saint Peter's in 12 readings. But if this first week should not come in the month of March, in another week or even in the third week, as the pontiff decides, these 12 readings shall be done, and they who are to be ordained are ordained".
} 
One might also mention that the record of Gregory's council in the manuscript's opening locates that meeting also to the basilica of Saint Peter ("IN BASILICA BEATI PETRI APOSTOLI"), and also, in the subscriptions to the council, records the allegiances of the many priests who attended in Rome's titular churches, providing a handy list of all of Rome's significant ecclesiastical buildings (41v-42r).

By adding the further references to Roman churches, and by setting these liturgical texts in the broader sweep of Roman history, its compilers intended to guide how that vision of Rome would be constructed and what resonances it would have in the minds of readers. Indeed, the collecting of ordines romani together into a single manuscript (a wholly Frankish endeavour since we possess no such collections originating in Rome) was always geared to construct a certain vision of Rome for an audience of Franks. We therefore should not treat such manuscripts as wholly disinterested records of the Roman liturgy. Wissembourg 91 represents a wholly unique collection of such texts, an individual creative endeavour in which a compiling hand and purpose makes itself visible to an exceptional extent. Mere replication of Roman text and ritual was not the priority, but to make that ritual serve new purpose. So, the compilers of Wissembourg 91 at the same time intervene to add Frankish practices to the narrative of the ordines romani set in Rome, consulting additional liturgical books and adding, also in appendix, rulings about customs like when to perform genuflection, or about the episcopal blessing during Mass which was a custom of the Frankish Church and not Rome. ${ }^{18}$ Of course, the episcopal blessing was also a particular sign of authority and prerogative for the Frankish bishop about whom this book is specially concerned. One discernible individual priority in this manuscript is a strong focus on the "scrutinies" in Ordo Romanus 11, the seven sessions of baptismal preparation during Lent. Here they are each given a title in red capitals and clearly marked out one from another; no other copy of Ordo Romanus 11 is so clear and so emphatic in marking out these seven occasions (FIG. 1). ${ }^{19}$

Additionally, Wissembourg 91 has the only copy of Ordo Romanus 11 that gives the Creed in full in both Greek and Latin. The presence of a Greek Creed in Ordo 11 had originally reflected the living Greek community present in Rome in the sixth and early seventh centuries. In the original form of the ritual (taking place at the third preparatory scrutiny during Lent), the acolyte asks if the family would prefer to confess in Latin or Greek, and proceeds to say the Creed in whichever they request. ${ }^{20}$ In the form of Ordo 11 found in other manuscripts, both creeds were given only as incipits, the Greek as simply Pisteuo his ena theon. Wissembourg 91 is the only manuscript of the text which offers both Latin and Greek

\footnotetext{
${ }^{18}$ An example Ordo Romanus 26, n.11, var.10, Andrieu 1931-1962, vol. III 1951, 328, "incipiat antefonam psalmis sicut in antephonario continetur et Gloriam in finem psalmi non cantent"; Appendix given by Andrieu as OR 28a, nn.24-25, Andrieu 1931-1962, vol. III 1951, 424-425, "Et sane scientes quod per singulas orationes sabbato sancto et pentecosten et omnem quadragesimam, exceptis diebus dominicis, genua flectere debemus; similiter IIII mensium tempora anni, id est primi, quarti, septimi et decimi mensis, cum feriis ipsarum observandum est; similiter et in dicto ieiunio vel vigiliis festivitatibus sanctorum faciatis. Et quando pontifex benedictiones super populum tradere uoluerit, archidiaconus, vel quem ipse iusserit, aspicit ad pontificem, ut ei annuat, et dicit ad populum: Humilitate uos ad benedictionem. Resp: Deo gratias. Si autem pontifex, ibidem non fuerit, supra scriptum habemus"; Wolfenbüttel Wissembourg 91, 66r.

${ }^{19}$ Wolfenbüttel Wissembourg 91, 56r "Secundum Scrutinium", "Tertium Scrutinium" repeated in margin also, 59r "Scrutinium Quartum", 59v "Scrutinium Quintum", "Scrutinium Sextum”, "Scrutinium Septimum” with marginal numerals.

${ }^{20}$ Andrieu 1931-1962, vol. II 1948, 434, "Qui lingua confitentur dominum nostrum Iesum Christum? Resp.: Graece...Et dicit acolitus symbolum graece, decantando in his verbis: Pisteuo his ena theon".
} 
forms in full, the Greek written out in phonetic Latin letters (57v-58r). Again, this addition was certainly helped by the consultation of other, related liturgical books. The likely source was a 'Gelasian Sacramentary of the Eighth Century', since both the Sacramentary of Gellone, c.770-780 (Paris BnF lat.14510) and the Sacramentary of Angoulême, c.800 (Paris BnF lat.816) give the Greek Creed in their baptismal rites. There were no Greek-speaking families in Francia to make this confession useful in the same way as it was in Rome. Nevertheless, the Wissembourg manuscript offers this Creed including accents to aid in its pronunciation. The Vespers after Easter given in Wissembourg 91 also included several Greek chants from the Roman tradition. While the practical utility of the Greek Creed was limited in Francia, it is likely that its recitation had a desirable liturgical role: reflecting the universality of baptism, a note of mysterious exoticism to non-Greek speakers or perhaps, within a recorded liturgical ceremony that skilfully integrated reference to Rome as model, it constituted an evocative recollection of the Apostolic City.

If we accept this model of an individualised transmission of Roman texts, it is always helpful to try and locate the manuscripts as much as possible, to try and gather for whom this recollection of Rome was intended. Andrieu had envisaged the manuscript as a product of the monastery of Wissembourg, in whose library it certainly was. ${ }^{21}$ However, Bischoff strongly disputed this identification on palaeographical grounds, and suggested, rather, the city of Worms. This was partly because of the interest in Saint Peter in the manuscript, while other texts now in the same binding that were clearly written in the same place include additional poetry on Saint Peter. ${ }^{22}$ The Carolingian cathedral of Worms was dedicated to Saint Peter, and still is today (a fact of some significance in liturgical terms, as we shall see). The Carolingian episcopacy and clergy of Worms were invested in the recreation of Roman liturgical models in their own city as a way to claim apostolic authority, but also with the specific devotional mentality of their age, as other bishops in other cities demonstrably were at the same time. The particular Bishop of Worms at the time the manuscript was created was Bernhar, who ruled that see from around 800 to $826 .{ }^{23}$ Bernhar was abbot of Wissembourg from 811 , the exact foundation to which the manuscript then came (gifted or bequeathed after his death?). It may be reductive to characterise the manuscript as a personal 'pontifical' of Bernhar, in the manner of later manuscripts of this type, but much of it does seem to represent liturgical priorities this august bishop, a relative by marriage and correspondent of Einhard, had. Bernhar was one of the senior participants at the council of Mainz in 813, which strongly stated the apostolic succession of bishops (a clear implication and focus of the PseudoClementine and Gregorian material in our manuscript), and also recommended baptism "secundum ordo romanus", meaning by this the inclusion of the pre-baptismal scrutinies so emphasized in Wissembourg 91. ${ }^{24}$ Bernhar also demonstrably went to Rome. He was sent there in 809 by Charlemagne with Bishop Jesse of Amiens and Abbot Adalhard of Corbie to present to Pope Leo III the findings of the Council of Aachen and the question of the

\footnotetext{
${ }^{21}$ Andrieu 1931-1962, vol. I 1965, 488-490; Vogel 1986, 227: “The Pontifical of Wissembourg”.

${ }^{22}$ Bischoff 1981, 93.

${ }^{23}$ Bischoff 2014, 512; On Bernhar, Hummer 2006, 82-83.

${ }^{24}$ Werminghoff (ed.) 1906, 259, "Hildibaldus, scilicet sacri palatii archiepiscopus, Rinholfus (of Mainz), et Arno (of Salzburg) archiepiscopi seu Bernharius”.
} 
filioque. ${ }^{25}$ Some of the unique details added to our text about Roman practice seem to have come from an eyewitness or personal acquaintance of Roman practices, and we know that Frankish visitors to Rome commonly observed and questioned Popes and their staff about exactly such details. A good example is the unique comment at the end of Ordo Romanus 42 about how only the Pope could celebrate the post-dedication masses in a church when he personally had dedicated it. ${ }^{26}$ Bernhar's own input into the manuscript would explain these otherwise unattested observations, and would also help to contextualise the vision of Rome here laid out. There are two possibilities: either Bernhar had the manuscript created for his own personal use, and these notes and details about Rome constituted for him a recollection of his own experience of Rome when he would perform his episcopal duties using it, or he had it created for one of the communities under his charge, where his personal notices about Rome had the authenticity of personal experience and thus greater power to make known the Rome he had seen to others who had not been there. Both possibilities foreground Frankish appropriation and use of their own particular image of Rome as the defining force in the manuscript's construction.

\section{Rome evoked within other early "pontificals"}

Other "pontificals" identified by Andrieu have a similarly intense and personalised relationship to Roman practice and to Roman topography. Another manuscript made up of ordines romani for similar purposes is now Cologne Dombibliothek MS 138. ${ }^{27}$ Also deemed by Andrieu a "petit" or "primitive" pontifical, the manuscript was likely created in Northern Italy in the first quarter of the ninth century. ${ }^{28}$ It is a smaller, slimmer manuscript than Wissembourg 91, and is principally made up of a singular collection of ordines romani evidenced in four other ninth-century manuscripts, called 'Collection B' in Andrieu. This Collection shares with Wissembourg 91 Ordo Romanus 1 (the stational Mass), 11 (baptismal preparations), 28 (Holy Week) and 42 (relic deposition), to which were added texts of indisputable Frankish origin: Ordo 37 (Ember days), Ordo 41 in a different recension (church dedication), a Frankish ordination ritual (Ordo de sacris ordinibus) and a set of laudes regiae of Frankish redaction, which invoke the saints for the imperial family, the Pope and the Bishop. Again, the transmission of ostensibly Roman originals was not straightforward, and these texts were placed alongside texts written outside Rome and often edited. Cologne 138 is a particularly interesting example. Like Wissembourg 91, the manuscript's compilers had checked other liturgical books to add, for example, a list of antiphons to be sung during the church dedication rite, 40r-v, and masses to be said during the scrutiny rituals, $26 \mathrm{v}-27 \mathrm{v}$ (neither being present in the ordines romani themselves). It also intensifies the Roman character of the Collection in several ways. Surrounding ordination, for example, one intervention peculiar to this

\footnotetext{
${ }^{25}$ In the Royal Frankish Annals, Pertz and Kurzt (ed.) 1895, 129: "mense Novembrio concilium habet de processione Spiritu sancti, quam questionem Iohannes quidam monachus Hierosolimis primo commovit; cuius definendae Bernharius episcopus Wormancensis et Adalhardus abbas monasterii Corbeiae".

${ }^{26}$ Andrieu 1931-1962, vol. IV 1956, 402: "Sciendum vero est ubi domnus apostolicus dedicat eclesiam praeter episcopos nulli licitum est infra ipsam ecclesiam missas celebrare".

27 Andrieu 1931-1962, vol. I, 1965, 101-108; Digitized at http://www.ceec.uni-koeln.de/ceec-cgi/kleioc/0010/exec/pagemed/\%22kn28-0138_e002.jpg\%22/segment/\%22body\%22.

${ }^{28}$ Bischoff 1998, 401 .
} 
manuscript gives the role of "cardinal priests" in ordination and discusses clerics called parrochiani, Roman institutions in origin. ${ }^{29}$ Furthermore, Cologne 138 is the first liturgical manuscript which we know to carry Ordo Romanus 40, a brief description of the ordination of the Pope himself by the bishops of Ostia, Albano and Porto. ${ }^{30}$ Again, we cannot imagine these texts to have any simple liturgical relevance for a Frankish celebrant. Few of the clergy reading such texts would ever be privileged to see such rituals, but a brief picture was here drawn for their contemplation, and, perhaps, to speak to an individual bishop about whence his own power ultimately came. They seem to imply that, like Wissembourg 91, the Italian "pontifical" Cologne 138 functioned on multiple levels, guiding liturgical rituals but also evoking Rome as an image that helped to shape how those rituals were understood.

Cologne 138, much like Wolfenbüttel 4175, also offers a piece of Roman papal history which had contemporary liturgical resonances: Gregory the Great's speech on the occasion of his institution of the "Sevenfold Litany" in Rome in 603 (42r-43r). ${ }^{31}$ By the Franks, this came to be identified with an annual liturgical event, the Litania Maiore, taking place on the $25^{\text {th }}$ April, steadfastly linked to Roman topography by the notices attached to the prayers said along the way, identifying where in Rome each would be said. ${ }^{32}$ In his speech, Gregory instructs the people of Rome to divide themselves, each to go to one of the seven Roman churches which are duly listed. ${ }^{33}$ Again we see a conspicuous interest of the creators of manuscripts that contain the ordines romani in documents of Rome's liturgical history, but particularly those which list the names of Roman Churches.

As with the Great Litany, there was particular interest in Roman topography linked to particular occasions during the year. Vienna Österreichische Nationalbibliothek Cod. ser. n. 2762 is another pontifical manuscript, now fragmentary. It was created at Saint-Emmeram in Regensburg in the first half of the ninth century. ${ }^{34}$ It may therefore have involved Bishop Baturich of Regensburg (817-848), another powerful Carolingian cleric linked to the royal family. He was Abbot of Saint-Emmeram as well, and the abbey created books for the use of the city's bishops. ${ }^{35}$ This manuscript gives Roman place names to the prayers it offers for the Great Litany of the $25^{\text {th }}$ April but also for the Vespers after Easter. ${ }^{36}$ Prior to its ordination

\footnotetext{
${ }^{29}$ Cologne Dombibliothek MS 138: 33v, "et tunc sacri ordines in aecclesia romana de eis qui dicuntur cardinales trade consuerunt. De parrochianis. Et in ipsis quattuor superscriptis mensium temporibus, qualicumque die domnus apostolicus voluerit ad sacros ordines parrochianos clericos per omnes aecclesios, si necessitas fuerit benedicit”; Andrieu 1931-1962, vol. IV 1956, 250, discussed at 242.

${ }^{30}$ Andrieu 1931-1962, vol. IV 1956, 289-297; Cologne 138: 34r.

${ }^{31}$ Discussed in Latham 2015, mentions Cologne 138 at: 13, n.47.

${ }^{32}$ E.g. in Vienna Cod.Ser.n.2762, Unterkicher (ed.) 1962, 60-61, "IN LITANA MAIORE. Ad sanctum Laurentium in Lucina...Ad sanctum Valentinum....ad fontem olbium (a corruption of Pontem Molbium)...ad crucem...in atrio...in alia atrio".

${ }^{33}$ Cologne 138, 43v, "I. Laetania crerici exeat ab ecclesia beati iohanne baptistae. II. Laetania uirorum ab ecclesia sancti martyris marcelli. III Laetania monachorum ab ecclesia martyrum Iohannis et Pauli. IIII Laetania ancillarum dei ab ecclesia beatorum martyrum cosmae et damiani. V Laetania feminarum cum iugatarum ab ecclesia beati primi et martyri Stephani. VI Laetania uiduarum ab ecclesia beati martyris Uitalis. Laetania pauperum infantum ab ecclesia beatae martyris caecilliae".

${ }^{34}$ Bischoff 1960, 218; Bischoff 1980, 240; Reconstructed and edited in Unterkircher (ed.) 1962.

${ }^{35}$ E.g. Verona Biblioteca capitolare MS. LXXXVII (82) a Pontifikal-Sakramentar was likely made there for Bishop Wolfgang (972-994).

${ }^{36}$ Unterkircher (ed.) 1962, 58-59, “Ad sanctum Andream...ad fontes...Sabbato ad sanctum Johannem ad (...)brum(...) Die dominica ad sanctos Cosmam et Damianum".
} 
ritual the manuscript gives some writings of Pope Gregory on the subject, as well as the "Ordo Qualiter" that sets the ritual in Saint Peter's. ${ }^{37}$ The manuscript also contains a version of what Andrieu calls Ordo Romanus 38, of which Andrieu was not himself aware. It describes a ceremony taking place on the Saturday of the so-called "Ember Days", Roman festivals that took place four times a year. ${ }^{38}$ Unlike Andrieu's edited version based on a number of eleventh-century and later manuscripts, this manuscript represents a much earlier Carolingian recension. Though a text written in Francia and describing a Frankish ceremony, it preserves the name of Saint Peter's as the "station", just as the Ordo Qualiter and Wissembourg 91's intervention in Ordo 15 did:

Finita oratione, leuantur uexilla sanctae crucis una cum cereostatariis et pergunt omnes in ordine suo cantantes antyphonam de tribulatione usque ad sanctum petrum quo statio fieri debet. ${ }^{39}$

Like the Great Litany, the Ember Days were very closely associated with particular Roman places. Wednesday was at Santa Maria Maggiore, Friday at Santi Apostoli and the Saturday, the time of ordination itself, at Saint Peter's. ${ }^{40}$ The Saturday even maintained an old name from Rome custom. Even in Francia it was called in xii lectionibus ad sanctum Petrum. This special title is maintained by all of the Ordo Romanus manuscripts, including Vienna ser.n.2762, which entitled Ordo 28: Ad XII Lectiones Agendas. ${ }^{41}$ Where the Ember Days are noted in Gospel capitularies, Sacramentaries and Antiphoners, as part of the stational liturgy therein contained, these three Roman church names are almost invariably given.

\section{The Stational Liturgy of Rome and "The Pontifical of Paris"}

The linking of liturgical festivals to particular Roman church names was a feature of the "stational liturgy" of Rome, a phenomenon that was of intense interest to the Carolingians. Laid out in Roman sources like the Gregorian Sacramentary, it involved the Pope processing to different churches in Rome throughout the year to celebrate mass at each, uniting the city's many churches under the single Pontiff. In Roman liturgical books, these churches were given as notices, notices steadfastly maintained by those who copied these books in Francia, and even, as we saw, kept when ceremonies were excerpted from these books and placed in a new context never envisaged in Rome, for example a pontifical. ${ }^{42}$ Thus, Roman church names would have been well known to any ninth-century reader of Frankish liturgical books, and resonated with liturgical meaning, whether or not the reader had ever been to Rome itself (and would have acquired even greater meaning if they had). As in the Ordo Romanus manuscripts, the liturgy was strongly associated with Roman topography, even if the liturgy was creatively adjusted as we have seen. Yet there were likely more direct liturgical usages made of these stational indications as well.

\footnotetext{
${ }^{37}$ Unterkircher (ed.) 1962, 102-103.

${ }^{38}$ Andrieu 1931-1962, vol. IV 1956, 257-269.

${ }^{39}$ Unterkiercher (ed.) 1962, 92, "When the prayer is finished, they lift up the banners of the holy cross along with candles and they all process in their order, singing the antiphon De tribulatione until Saint Peter's, where the station should be done".

${ }^{40}$ As in the Gregorian Sacramentary, Deshusses (ed.) 1971, 137-141 (Spring), 230-231 (Summer), 275-277 (Autumn), 297-299 (Winter); Baldovin 1987, 155-156.

${ }^{41}$ Untekircher 1962, 91, "how to do the 12 readings".

${ }^{42}$ Baldovin 1987, 109-166; Häußling 1973; Dorn 1917.
} 
There is sufficient evidence to believe that most great Frankish cities and monasteries actively imitated Rome's stational liturgy and employed these notices of Roman churches found in liturgical books as a model for how to do so. ${ }^{43}$ The indications in our manuscripts suggest that both Worms and Regensburg also employed this system. Telling is that Wissembourg 91's scribes added a special dialogue announcing the stational church for the day into the structure of Ordo 1, the only manuscript copy of this text to do so (suggesting the actual employment of Ordo 1 as a model for a stational liturgy in Francia). ${ }^{44}$ There remains particularly good documentation for the see of Metz. At the end of Gospel book, Paris BnF lat.268, is an eighth-century list of stational churches from Metz, giving a Metz church to each day in Lent equivalent to the Roman church's customs. ${ }^{45}$ The bishop likely responsible for this list was Angilram of Metz, bishop from 768 to 91 and he is also recorded as paying "stationarii" clerics chosen to keep the stations in the manner of the Roman church during Lent. ${ }^{46}$ The Metz list models itself on the Roman tradition. We see this in the Ember Days, for example. In Metz, Wednesday takes place in a Marian Church, as it did in Rome, while the Saturday, itself linked to Saint Peter's basilica consistently in the Carolingian testimony, takes place at the Metz church of Saint Peter in the episcopal complex. ${ }^{47}$ Thus, where Saint Peter's is listed as the location for this feast in the ordines romani, it could stand equally for the Roman basilica and the Frankish church which took its place in the stational system as practiced here, self-consciously linking the Frankish church to the Roman model. Both Worms and Regensburg, notably, had cathedrals dedicated to Saint Peter, where the Ember Saturday rituals seemingly took place. In Ordo 38, as presented in Vienna cod. Ser. n.2762, sanctum petrum was both the Roman church, and Regensburg cathedral.

There is another Carolingian pontifical that provides particularly good evidence of this phenomenon, Paris Bibliothèque de l'Arsenal 227, the "Pontifical of Paris". ${ }^{48}$ The manuscript has been located to the area around Paris on the basis of litanies it contains, and likely originated in Saint-Maur-des Fossés, a monastery just outside the city. It is important to continue to ask why "pontificals", the episcopal liturgical books, were so often created and perhaps read in monasteries, suggesting once again that such books were commonly used in ways beyond direct liturgical performance. This example has been dated to the years $870-880$. A heroic exercise in liturgical compilation, this manuscript gives quite remarkable narratives of liturgical rituals in an unmatched and almost overwhelming depth. Biblical readings in full, chants and psalms, and rubrics and ordines giving actions in great detail were all written into the narratives of the rituals it offers. Certainly the compiler knew the ordines romani edited by Andrieu, and employed these as well, giving Roman rites as alternatives and points of interest, while at the same time offering precious and often unique indications about Frankish

\footnotetext{
${ }^{43}$ Häußling 1973, 189-212, particularly 199.

${ }^{44}$ Andrieu 1931-1962, vol. II 1948, 102, Ordo 1, n. 108 "Deinde venit archidiaconus cum calice ad cornu altaris et adnuntiat stationem ita: Illo die veniente statio erit ad sanctum Illum, foras aut intus ciuitate. Resp: Deo gratias".

${ }^{45}$ Edited in Klauser 1974; Claussen 2004, 276-286.

${ }^{46}$ Edited in Andrieu 1930, 356, "Stationarii namque XV qui per totam quadragesimam stationes suas iuxta consuetudinem sedis apostolice custodiunt".

${ }^{47}$ Klauser 1974, 28, "Feria IIII hebdomada I statio ad sanctam mariam infra episcipio... Sabbato in XII lectionibus statio ad sanctum petrum infra episcopium".

${ }^{48}$ Edited in Martini 1979; Digitized at https://gallica.bnf.fr/ark:/12148/btv1b55005681f.r=pontifical\%20poitiers?rk=$85837 ; 2$.
} 
traditions. Among the Roman, the Pontifical of Paris also offers a Greek Creed in full during the Lent scrutiny, with an interlinear Latin translation (54v-56r). This manuscript does adjust the ritual, the Greek Creed is given over a male child, while the Latin over a female, a clear indication that the Roman ritual of reciting Greek was actively being employed and adjusted in Francia. ${ }^{49}$ Such a custom was not simply recorded pro forma, but a new role for it was imagined in this new context, and therefore a new meaning. Among many other nods to Roman practice, the rituals surrounding Holy Week actively embrace the stational system and give numerous details. Maundy Thursday takes place over three stations (152v, 154r, 155v), and the text gives the Roman equivalent to the last as Saint John in the Lateran:

ad ecclesiam maiorem stationis eiusdem celebritatis, quae in sede quidem apostolica ad sedem Iohannem in Lateranis agitur, in caeteris uero urbibus seu monasteriis pro oportunitate et congruentia unuscuisque loci. ${ }^{50}$

Here, not only are stations specifically stated to take place in the Frankish cathedral, or even in a monastery, but the station performed there is linked to the Roman system and dependent upon it. For Holy Week and the week after, Roman station names are also given to each mass, in much the same way. The Pontifical of Paris, like the other manuscripts I have discussed, aims to offer liturgical instructions that allowed the reader, celebrant or interested observer, to imagine Rome as they read them. The "pontifical" format, as above, was uniquely suited and, it seems, purposefully designed to create links between the cathedral and urban space within which the bishop performed his liturgical duties, and the topography of Rome and the rituals that unfolded there. In the particular example of the Pontifical of Paris, and potentially elsewhere, the space of a monastery could be likewise transformed for the observers and participants of ceremonial underway there. Just as we might see the particular picture of Rome drawn by Bernhar of Worms' "pontifical", Wissembourg 91, shaped by the personal input and institutional requirements of the Bishop of Worms, so too does the "Pontifical of Paris", Arsenal 227, shape its record of the Roman stational liturgy to its institutional context, the monastery of Saint-Maur-des-Fossés.

\section{Conclusions}

In his De animae ratione, Alcuin of York, Charlemagne's intimate and among the most influential intellectuals of the Carolingian world, wrote that when reading about Rome, one created a Rome in the mind, from memory. ${ }^{51}$ Even those who had never been there, would create an image of the city as they read. Scholarship has linked this remark to texts like the Einsideln Itinerary, which lists Roman churches and monuments on the path of pilgrimage. ${ }^{52}$ The manuscript transmitting this text, Einsideln Stiftsbibliothek Cod. 326, compiled probably at

\footnotetext{
${ }^{49}$ Martini 1979, 63, "accipiens acolitus unum ex ipsis infantibus masculum...et interrogat eum presbiter grece qua lingua confitentur...et dicit acolitus symbolum grece...hoc finito iterum accipit alter acolitus ex ipsis infantibus feminam sicut supra et interrogat eum presbiter latine...".

${ }^{50}$ Martini 1979, 165, "At the great church where this station is celebrated, which in that Apostolic see is done at Saint John in the Lateran, but in other cities or in monasteries is done in whichever place presents itself for opportunity and suitableness".

${ }^{51}$ PL 101, 642.

${ }^{52}$ Maskarinec 2018, 144-145.
} 
Reichenau monastery in the ninth century, additionally recorded inscriptions seen in Rome and poems on the city, but it also has a single Ordo Romanus, otherwise unattested, edited in Andrieu as Ordo Romanus $23 .^{53}$ This describes the liturgical practices of the Pope during Holy Week. Thus, liturgical texts describing Roman practice, particularly when placed among discussions and descriptions of Roman topography, could potentially serve a similar function to the Itinerary, allowing a reader a view onto Rome's imagined space as a liturgical map on which ceremonies unfolded. But more than the Itinerary, the Ordo Romanus also offered liturgical ceremonies as models for the reader to actively imitate on the stage of their own church or monastery. I would argue that the "pontifical" manuscripts examined above had this function of the ordines romani at the centre.

Rome was a highly complex reality to the Carolingians: its liturgical customs, its sacred history, the map of its topography, none of these visions of the city could be entirely separated from another. Our manuscripts themselves show this by offering such rich testimony to Roman papal history at the same time as liturgical texts to perform. When the Franks attempted to imitate the Roman liturgy therefore, they did not do so apart from their own attempts to appropriate the city's history as their own. The Carolingian clergy were desperate for Roman relics, replanting them in their own churches and monasteries to feel a link to the martyrs of Rome and appropriate their special protection. ${ }^{54}$ Great cathedrals and monasteries were rebuilt on Roman patterns, including notably both Metz cathedral and Saint-Denis. ${ }^{55}$ This often involved the construction of a confessio, a structure allowing pilgrims to venerate the relics beneath the altar. The creator of Wissembourg 91 even added a mention of such a structure to Ordo 1, showing that these adjustments entailed liturgical modifications that the Carolingians then wrote back into Roman liturgical texts! ${ }^{56}$ It was the same people who remade their cathedrals and bartered for the bodies of the Roman martyrs who also wrote these ordines romani manuscripts, and who evidently saw a liturgical pattern in them which they could follow, on a stational framework itself borrowed from Rome.

If we are to understand the ordines romani manuscripts, properly, we have to take seriously the multiple potential and potentially co-existing functions of liturgical manuscripts. One of the difficulties Andrieu encountered with the ordines romani manuscripts was the inflexibility of his own definition of terms like "pontifical". ${ }^{57}$ To him this meant a book for the use of a bishop, it precluded that the book had any other function than liturgical usage, even the study of the liturgy. But the ordines romani manuscripts demand that the liturgy was read carefully and studied thoughtfully. Before any ritual was performed from the script of an Ordo Romanus, some adjustments would have to be made to address the new Frankish setting (which are often, as our manuscripts show, then written into later copies of the same texts). But our manuscripts also allowed, even encouraged, the reading of the liturgy as an object of study and meditation. They place the liturgy in a Roman-centred history, in direct continuation with the practices of Gregory the Great, the times of the martyrs the Carolingians valued so highly, and, ultimately, with Saint Peter himself. They create a map of Rome's many

\footnotetext{
${ }^{53}$ Andrieu 1931-1962, vol. IV, 1956, 137.

${ }^{54}$ McKitterick 2009, 95-97; Claussen 2004, 258-261; Smith 2000.

${ }^{55}$ Emerick 2011; Claussen 2004, 249-255 Heitz 1979.

${ }^{56}$ Andrieu 1948, 103 Ordo 1, n.124, var.6, "dicit ad populum: Ite missa est". Resp. "Deo gratias et pontifex descendit ad confessionem et orat".

${ }^{57}$ Rankin 2016; Hamilton 2011.
} 
churches, employing the stational liturgy, a system that they themselves reveal was a subject of deep interest and direct imitation among Carolingian liturgists. Notably, nowhere do these manuscripts demand stale imitation of the Roman practices or uniformity according to their model. The evocation of Rome was an intended effect in itself, this directed and shaped by the Frankish audience. It was also a central part of a persistent engagement, on this audience's part, with the multiple functions of liturgical text, which was not enclosed only in the context of performance, and which close study of manuscripts reveals to the modern eye.

\section{Arthur Westwell}

Pontifical Institute of Medieval Studies; University of Toronto arthur.westwell@utoronto.ca 


\section{BIBLIOGRAPHY}

Andrieu M. 1930: "Règlement d'Angilramne de Metz (768-793) fixant les honoraires de quelques fonctions liturgiques", RSR, 10, 3, 349-69.

Andrieu M. (ed.) 1931-1962: Les Ordines Romani du haut moyen âge, 5 vols, vol.I reprinted 1965, (Spicilegium Sacrum Lovaniense, 11, 23-24, 28-29) Louvain.

Aubert E. 2013: "When the Roman Liturgy became Frankish: Sound, Performance and Sublation in the Eighth and Ninth Centuries", Études Grégoriennes, 40, 57-160.

Baldovin J. 1987: The Urban Character of Christian Worship (Orientalia Christiana Analecta, 228), Rome.

Bischoff B. 1960-1980: Die Südostdeutschen schreibschulen und Bibliotheken in der Karolingerzeit, 2 vols, Wiesbaden.

Bischoff B. 1981: Mittelalterliche Studien: ausgewählte Aufsätze zur Schriftkunde und Literaturgeschichte, vol. III, Stuttgart.

Bischoff B. 1998-2014: Katalog der festländischen Handschriften des neunten jahrhunderts (mit Ausnahme der Wisigotischen), 3 vols., Wiesbaden.

Bullough D. 1991: "Roman Books and Carolingian Renovatio", in Carolingian Renewal, New York, 137.

Butzmann H. 1964: Kataloge der Herzog August Bibliothek Wolfenbüttel: Neue Reihe, vol.X, Die Weissenburger Handschriften, Frankfurt am Main.

Claussen M. 2004: The Reform of the Frankish Church: Chrodegang of Metz and the Regula Canonicorum in the Eighth Century, Cambridge.

Coeburgh C. and Puniet P. (eds): Liber Sacramentorum Excarsus, (Corpus Christianorum Continuatio Medievalis 47), Turnhout, 81-110.

Deshusses J. (ed.) 1971: Le sacramentaire grégorien: ses principales formes d'après les plus anciens manuscrits, vol.I., Freiburg.

van Dijk S. 1969-1970: "The Medieval Easter Vespers of the Roman Clergy", SEJG 19, 261-363.

von Dobschutz E. 1912: Das Decretum Gelasianum de libris recipiendis et non recipiendis, Leipzig.

Dorn J. 1917: "Stationsgottesdienste in frühmittelalterlichen Bischofsstädten”, H. Gietel and G. Pfeilschifer (ed.) Festgabe für A. Knöpfler, Freiburg, 43-55.

Duchesne (ed.), 1886: Le Liber Pontificalis, texte, introduction et commentaire, vol.1, Paris.
Eizenhöfer L., Mohlberg L. and Siffrin P. (eds.) 1960: Liber Sacramentorum Romanae Aeclesiae Ordinis Anni Circuli (Cod. Vat. Reg. lat. 316/Paris Bibl. Nat. 7193 41/56) (Rerum Ecclesiasticarum Documenta. Series Maior, Fontes 4), Rome.

Emerick J. 2011: "Building more romano in Francia during the third quarter of the eighth century: the abbey church of Saint-Denis and its model" in C. Bolgia, R. McKitterick, and J. Osborne (eds.), Rome Across Time and Space: Cultural Transmission and the Exchange of Ideas, c.500-1400, Cambridge, $127-$ 150.

Gittos H. and Hamilton S. (eds.) 2015: Understanding Medieval Liturgy: Essays in Interpretation, Ashgate.

Hamilton S. 2011: "The Early Pontificals: AngloSaxon Evidence Reconsidered from a Continental Perspective", in D. Rollason, C. Leyser, and H. Williams (eds.), England and the Continent in the Tenth Century, Turnhout, 411-428.

Häußling A. 1973: Mönchskonvent und Eucharistiefeier. Eine Studie über die Messe in der abendländischen Klosterliturgie des frühen Mittelalters und zur Geschichte der Meßhäufigkeit, (Liturgiewissenschaftliche Quellen und Forschungen, 58) Münster.

Heitz C. 1979: "L'architettura dell'eta carolingia in relazione alla liturgia sacra", Convegni del centro di studio sulla spiritualitá medieval 28, 337-362.

Hen Y. 2001: The Royal Patronage of Liturgy in Frankish Gaul to the death of Charles the Bald (877), (Henry Bradshaw Society Subsidia, 3) Woodbridge.

Hummer H. 2006: Politics and Power in Early Medieval Europe: Alsace and the Frankish Realm, 6001000, Cambridge.

Kaczynski B. 1988: Greek in the Carolingian Age: The St Gall Manuscripts, Cambridge Massachusetts.

Klauser T. 1974: "Eine stationsliste der Metzer kirche aus dem 8.Jahrhundert Wahrscheinlich ein werk Chrodegang", in Gesammelte Arbeiten zur Liturgiegeschichte, kirchengeschichte und Cristlichen Archäologie, Münster, 22-45.

Latham J. 2015: "Inventing Gregory the Great: Memory, Authority and the Afterlives of the Laetenia Septiformis", ChHist 84, 1-31.

Martini A. 1979: Il Cosiddetto Pontificale di Poitiers (Paris, Bibliothèque de l'Arsenal, cod.227), Rome.

Maskarinec M. 2018: City of Saints: Rebuilding Rome in the Early Middle Ages, Philadelphia. 
McKitterick R. 1997: "Unity and diversity in the Carolingian Church" in R.N. Swanson (ed.), Unity and Diversity in the Church (Studies in Church History, 32), Cambridge Massachusetts, 59-82.

McKitterick R. 2009: "Les Perceptions Carolingiennes de Rome", in Falkowski, W. and Sasser, Y. (eds.), Le monde carolingien: Bilan, Perspectives, champs de recherches, Actes de colloque international de Poitiers, Centre d'Études Supérieures de civilisation mediévale, 18-20 novembre, Turnhout, 83-102.

McKitterick R. 2011: "Roman texts and Roman history in the early Middle Ages" in McKitterick et al. (eds.) Rome Across Time and Space, 19-34.

Metzger M. 1914: Zwei karolingische Pontifikalien vom Oberrhein, Freiburg.

Parkes H. 2015: The Making of Liturgy in the Ottonian Church: Books Music and Ritual in Mainz 950-1050, Cambridge.

Palazzo E. 1993: Histoire des livres liturgiques: Le Moyen Âge, origins au XIIIe siècle, Paris.

Palazzo E. 2014: "Le livre liturgique et son pouvoir d'incarnation de la liturgie des èglises", Chiese locali e chiese regionali, Settimane di studio del centro italiano di studio sull'alto medioevo, 61, 807-827.

Pertz G.H. and Kurzt F. 1895: Monumenta Germaniae Historica: Scriptores Rerum Germanicarum 6: Annales Regni Francorum, Hannover.

Plotzek J. 1998: Glaube und Wissen im Mittelalter die Kölner Dombibliothek, Munich.
Rankin S. 2016: "Carolingian Liturgical Books: Problems of Categorization", Gazette du Livre Médiéval 62, 21-33

Reynolds R. 1988: “A south Italian Mass Commentary”, Mediaeval History 50, 626-670.

Saint-Roch P. (ed.) 1987: Liber Sacramentorum Engolismensis, Corpus Christianorum Series Latina 159C, Turnhout.

Smith J. 2000: "Old Saints, new Cults: Roman relics in Carolingian Francia", in J. Smith (ed.) Early medieval Rome and the Christian West: essays in honour of Donald A. Bullough, Leiden, 317-340.

Stäblein B. 1968: "Gregorius Praesul, der Prolog zum römischen Antiphonale", in K. Vötterle, R. Baum and W. Rehm (eds.), Musik und Verlag. Karl Vötterle zum 65. Geburstag, Kassel, 537-61.

Strecker K. (ed.) 1923: Monumenta Germaniae Historica Poetae aevi Karolini IV, fasc. III, Hannover.

Unterkircher F. (ed.) 1962: Das Kollektar-Pontifikale des Bischofs Baturich von Regensburg (817-848) (Cod.Vindob.ser.n.2762) (Spicilegium Friburgense, 8), Freiburg.

Vogel C. 1986: Medieval Liturgy: An Introduction to the Sources, Revised and Translated by W. Storey and N.K. Rasmussen, Washington.

Weminghoff A. (ed.) 1906: Monumenta Germaniae Historica Leges 2: Concilia Aevi Karolini, pars I Hannover and Leipzig.

Willis G. 1964: "Ember Days", Essays in Early Roman Liturgy, London, 49-97. 


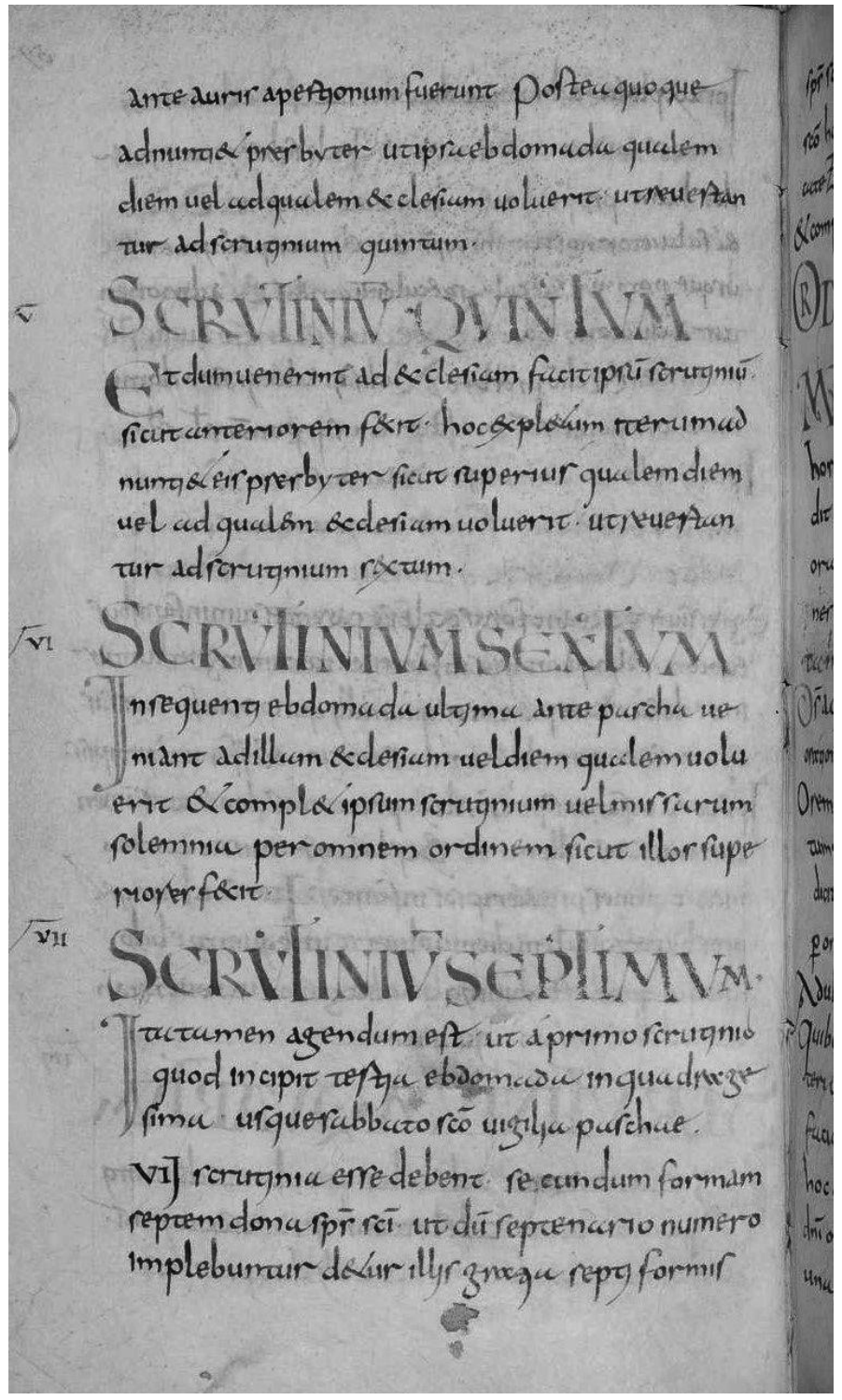

Fig. 1 - Wolfenbüttel Herzog August Bibliothek Weissembourg 91, folio 59v (@ HAB Wolfenbüttel: Cod. Guelf. 91 Weiss. http://diglib.hab.de/mss/91-weiss/start.htm). 